\title{
Nitric oxide modulates the antidepressant-like effect of acute lithium administration in the mouse forced swimming test Mehdi Ghasemi*1, Hamed Sadeghipour ${ }^{1}$, Hamid Reza Sadeghipour ${ }^{2}$ and Ahmad Reza Dehpour ${ }^{1}$
} \author{
School of Medicine, Medical Sciences/University of Tehran, Tehran, Iran \\ * Corresponding author \\ from International Society on Brain and Behaviour: 3rd International Congress on Brain and Behaviour \\ Thessaloniki, Greece. 28 November - 2 December 2007 \\ Published: 17 April 2008 \\ Annals of General Psychiatry 2008, 7(Suppl I):S26I doi:10.I I86/I744-859X-7-SI-S26I
}

Address: ${ }^{1}$ Department of Pharmacology, School of Medicine, Medical Sciences/University of Tehran, Tehran, Iran and ${ }^{2}$ Department of Physiology,

This abstract is available from: http://www.annals-general-psychiatry.com/content/7/SI/S26I

(c) 2008 Ghasemi et al.; licensee BioMed Central Ltd.

\section{Background}

Lithium has largely met its initial promise as the first drug to be discovered in the modern era of psychopharmacology, yet no definitive mechanism for its effect has been established. In the present study we evaluated the involvement of L-arginine/nitric oxide (NO)/cGMP pathway in the antidepressant-like effects of acute lithium administration in the mouse forced swimming test (FST).

\section{Materials and methods}

Male NMRI mice weighting 23-30 g (Pasteur Institute) were used throughout the study. The FST was conducted using the method of Porsolt [1]. The locomotor activity was also evaluated by an open-field test.

\section{Results}

Lithium, at 30 and $100 \mathrm{mg} / \mathrm{kg}$, significantly reduced the immobility times of mice in the FST, whereas at lower doses $(0.5,5$ and $10 \mathrm{mg} / \mathrm{kg})$ had no effect on the immobility time. The NO synthase (NOS) inhibitor NG-nitro-Larginine methyl ester (L-NAME), at 10 and $30 \mathrm{mg} / \mathrm{kg}$, and the selective neuronal NOS inhibitor N $\omega$-propyl-Larginine (L-NPA), at 5 and $15 \mathrm{mg} / \mathrm{kg}$, had no significant effects on the FST, whereas they significantly decreased the immobility time at 100 and $30 \mathrm{mg} / \mathrm{kg}$, respectively. Combination of non-effective dose of lithium $(10 \mathrm{mg} / \mathrm{kg})$ with low doses of L-NAME $(30 \mathrm{mg} / \mathrm{kg})$ or L-NPA $(15 \mathrm{mg} / \mathrm{kg})$ significantly reduced the immobility times in the FST. Moreover, the guanylyl cyclase inhibitor ODQ at $50 \mathrm{mg} /$ $\mathrm{kg}$ significantly decreased the immobility time of mice, whereas it had not significant effects on the FST at 2, 10 and $20 \mathrm{mg} / \mathrm{kg}$. Combination of lithium $(10 \mathrm{mg} / \mathrm{kg})$ with $20 \mathrm{mg} / \mathrm{kg}$ ODQ significantly decreased the immobility times in the FST. Non-effective doses of L-arginine (750 $\mathrm{mg} / \mathrm{kg})$ or sildenafil $(5 \mathrm{mg} / \mathrm{kg})$ significantly reversed the antidepressant-like effect of $30 \mathrm{mg} / \mathrm{kg}$ lithium in the FST. Neither of the drugs had effect on the locomotor activity.

\section{Conclusions}

These data indicate the involvement of L-arginine/NO/ cGMP pathway in the antidepressant-like effect of lithium in the mouse FST and also might suggest the concurrent administration of NOS inhibitors and lithium as an appropriate strategy for treatment of depression.

\section{Acknowledgements}

M Ghasemi will hopefully present this study.

\section{References}

I. Porsolt RD, Bertin A, Jalfre M: Behavioural despair in mice: a primary screening test for antidepressants. Arch Int Pharmacodyn Ther 1977, 229:327-336. 